\title{
Influence of Work Life Balance Policies on Employee Job Satisfaction In Kenya's Banking Sector; A Case of Commercial Banks in Nairobi Central Business District
}

\author{
${ }^{1}$ Jane Nyambura Mukururi, ${ }^{2}$ Dr. James Mark Ngari \\ ${ }^{1}$ School of Business and Economics Kenya Methodist University \\ ${ }^{2}$ Faculty of Business, ICT and Communication studies Saint Paul's University
}

\begin{abstract}
The aim of this research was to analyze the relationship between work life balance policies and employee job satisfaction. Work life balance entails attaining equilibrium between professional work and other activities, so that it reduces friction between official and domestic life. Job satisfaction refers to the attitude people have towards their job and the organisations they work for. The quality of work life policies is increasingly becoming part of the business strategy and the focus is on the potential of these policies to influence employee's quality of working life and more importantly to help them maintain work-life balance with equal attention on performance, commitment at work and job satisfaction. This study proves to be a milestone for the researchers, policy makers and students to properly understand the concepts of employee job satisfaction, work life balance and their relationship. The study employed descriptive research design. The target population was Two hundred and Forty Respondents. Data was collected using questionnaires, and analysed using Statistical Package for Social Sciences. The findings of this study emphasized that each of the work life balance policies on its own is a predictor of job satisfaction. The goodness of fit, $R=0.618$ showed a good strength of the relationships between independent variables and the dependent variable. The result of this study makes the recommendation that managers in banks should improve the work life balance policies offered to employees in order to increase their job satisfaction, to improve staff commitment and productivity.
\end{abstract}

Key words: Work Life Balance policies, Employee Job Satisfaction, Banking Sector, Commercial Banks

\section{Introduction}

Work life balance policies are programs established by an employer that offer employees options to address work and personal responsibilities. Job satisfaction can be defined as being the positive emotional reactions and attitudes an individual has towards his/her job Robbins (2003).The term Work Life balance gained importance in the late 1960s due to concerns about the effects of work on the general well being of employees. Up until the mid 1970s, employers concern was on work design and working conditions improvement. However, in the next decade of 1980s, the concept of quality Work Life gained importance and it encompassed aspects that affect employees such as job satisfaction, reward systems, physical work environment, employee involvement, rights and esteem needs Cummings and Worley (2005).

In 2001 Forty one percent of managers in an institute of management survey felt that the quality of working life had got worse over the last three years. Much of the pressure for work-life balance policies originates from the changing demographic makeup of our potential workforce, changing social roles, the changing responsibilities of organizations and legislative pressure. Increasing numbers of women in the workforce wishing to combine family and work responsibilities is an obvious driver for what were initially called family friendly policies and which quickly work life balance policies became. This legacy does cause problems for the implementation of work life balance policies. The ageing workforce is another demographic change which has raised the importance of work life balance for employees .Older employees may wish to remain in work, but work fewer hours or different shift patterns. In a tight labour market with a shortage of needed skills employers are forced into developing policies which can attract and retain groups of workers who might previously left the organization.IRS (2002) found that the most popular reason employers introduce work life balance policies were recruitment and retention.

In Kenya there is a push towards the 24/7 Economy. This means that more flexibility is needed to cover round the clock peaks. There is much evidence of work intensification and this faster pace has been associated with much greater levels of stress in organizations. Holbeche (2002) found that employees were experiencing anxiety, workload, and loss of control, pressure, long hours and insufficient personal time. Such experiences are likely to encourage a reassessment of values in workers. And there is also evidence that younger people entering the labour market are much less willing to sacrifice their personal lives for total commitment to work. Values and expectations appear to be changing. 
In Kenya most companies lack policies that support the well being of their employees that according to a survey done by Strathmore Business School in 2011.The banking sector in Kenya has changed drastically. Most major banks have their busiest branches in the Central Business District. Employees working in the central business district work longer hours, their work is more complex and intensified therefore experiencing a lot of work pressure and creating a culture of poor work life balance. One of the biggest contributions to the study of job satisfaction was the Hawthorne studies in the 1920s. These studies ultimately showed that novel changes in work conditions increase productivity. The profitability and productivity of organizations depends on the performance and commitment of its employees. Every employee has a personal and professional life; both of these are very difficult to separate. If an organization wishes to have better productivity and more commitment from employees then they have to be happy and satisfied. This is achieved when an individual's right to have a fulfilled life inside and outside work is accepted and respected, to the mutual benefit of the individual and the organization.

Organizations are social systems where human resources are the most important factors for effectiveness and efficiency and need effective managers and employees to achieve their objectives. Organizations cannot succeed without their personnel efforts and commitment. Job satisfaction is critical to retaining and attracting well-qualified personnel. Exceptional organizations have leaders that create work environments where people can achieve work-life balance and well being as they define it for themselves Spinks (2004). A satisfied work force is essential for the success of organizations and their businesses. Dissatisfied employees make organizations dysfunctional, damaging their financial performance. Job satisfaction and work life balance are more likely to drive employees to remain with their current employers than benefits and salary, according to a recent poll by the Washington-based American Psychological Association.

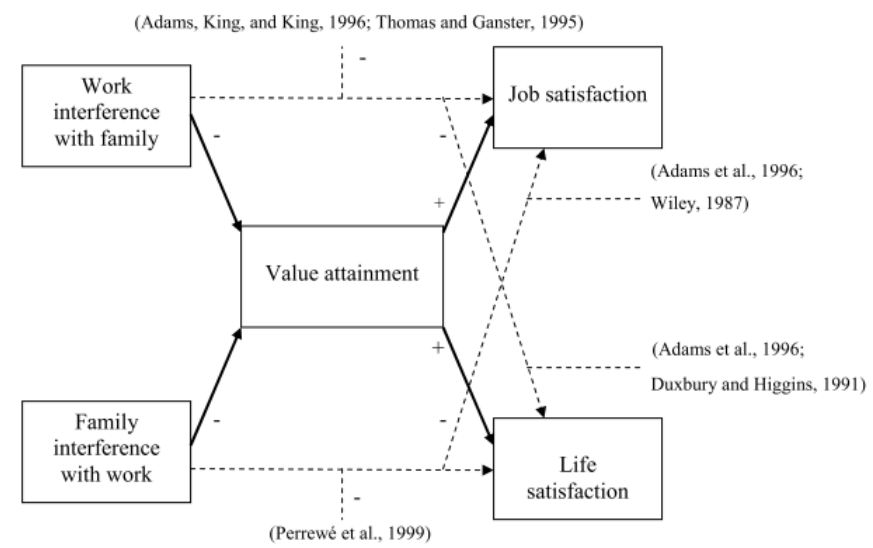

Figure 1: The relationship between Work Life balance and Job Satisfaction

\section{Statement of the problem}

The ultimate performance of organizations depends on the performance of its employees, which in turn depends on numerous factors. These factors can be related to work or family or both. Work life balance enhances efficiency and thus, the productivity of an employee increases. The satisfaction or dissatisfaction of the workers affects the performance of the organization.

There is growing evidence that current trends in employment conditions may be eroding levels of job satisfaction and directly damaging the physical and mental health of employees. The radical changes in the world of business, like factors such as globalization, information technology, world business competitiveness, and scarcity of natural resources have changed employee's outlook of how a good company is defined. The trend in past was to include, financial figures in defining "a good company". Latest trends like, ethics, quality of work life and job satisfaction are now considered important predictors of sustainability and viability of business organizations.

New working practices and rapid technological advances are changing the nature of many jobs. A job is compatible with an employee when it involves duties and assignments that the employee finds interesting, when it requires abilities that the employee possesses and when it provides rewards that the employee finds desirable. Too much emphasis on work frequently results in feelings of loneliness and frustration. Job satisfaction typically increases with improved life balance, which in turn increases employee loyalty, creativity and productivity.

In Kenya, the banking Sector has evolved drastically, Commercial Banks are very competitive and this has resulted in coming up with measures geared towards attracting new customers and retaining the existing ones in order to have a larger market share. Banks in Kenya are now bringing in more profits by 
being customer focused. In order to attain this they have increased their opening hours, introduced more products, opened up more branches and have adopted the latest IT Infrastructure. This has led to their Employees working longer hours, having a greater and more complex workload, being moved from one branch to another, therefore, experiencing a lot of work pressure and creating a culture of poor work life balance resulting to their employees becoming highly dissatisfied with their jobs. Banks are now experiencing high Labor turnover, absentees and they have incur huge losses caused by employee negligence.

\section{Objectives of the study and Literature Review}

The general objective of the study was to establish the Influence of work life balance policies on Employee job satisfaction in Commercial Banks. Specifically the study was guided by the following objectives; to assess whether flexible work practices, Leave Provisions, Welfare Policies, Job Design in influence employee job satisfaction in Commercial Banks in the CBD

The earliest view of the relationship between work and home was that they are segmented and independent and do not affect each other. Blood and Wolfe (1960) who were pioneers of this perspective applied this concept to blue collar workers. However, this view of segmentation was challenged by researchers who demonstrated that work and family are closely related domains of human life Burke and Greenglass (1987).

In the Spill over theory researchers suggested that workers carry the emotions, attitudes, skills and behaviours that they establish at work into their family life and vice-versa. Spill over can be positive or negative. The Compensation theory proposed that workers try to compensate for the lack of satisfaction in one domain (work or home) by trying to find more satisfaction in the other (Lambert, 1990). Clark,(2000) presented a "crossing borders" theory, according to this theory, the flexibility and permeability of the boundaries between people's work and family lives will affect the level of integration, the ease of transitions, and the level of conflict between these domains. Boundaries that are flexible and permeable facilitate integration.

Voydanoff (2001) have found significant interdependence between the roles that each requires workers to perform work-family conflict practices when balance cannot be achieved between the two roles. Either role may demand more time or more responsibilities, potentially leading to a reduction in. Prior research by Haar (2007) and Roehling(2003) on the spill over effect have examined if work and home roles should be integrated or segmented. According to the type of provisions offered employees, there may be a combination of both work spill over and home spill over. Non-traditional working arrangements have been introduced by many corporations, such as job sharing, telecommuting and compressed work weeks to ensure employee flexibility Hyland (2005).

\section{Job Satisfaction Theories}

The earliest theory on job satisfaction is the Affect theory, the main premise of this theory is that satisfaction is determined by a discrepancy between what one wants in a job and what one has in a job. Another theory is the dispositional theory it suggests that an individual has innate dispositions that cause them to have tendencies toward a certain level of satisfaction. The opponent process theory is another theory that attempts to explain job satisfaction, according to this theory, emotional events such as criticisms or rewards, elicits. Primary processes that give way to emotions that are steady with the event in question and opponent processes induces. The Equity Theory suggests that if an individual thinks there is an inequality between two social groups or individuals, the person is likely to be distressed because the ratio between the input and the output are not equal.

The concept of discrepancy theory explains the ultimate source of anxiety and dejection. An individual, who has not fulfilled his responsibility feels the sense of anxiety and regret for not performing well, they will also feel dejection due to not being able to achieve their hopes and aspirations. Frederick Herzberg's Two-factor theory attempts to explain satisfaction and motivation in the workplace. This theory states that satisfaction and dissatisfaction are driven by different factors motivation and hygiene factors, respectively. Motivation can be seen as an inner force that drives individuals to attain personal and organizational goals. Hygiene factors include aspects of the working environment such as pay, company policies, supervisory practices, and other working conditions.

The research studies providing support for the current study suggests that an organization that accommodates the work family balance concerns and constraints of its employees is able to sustain a higher level of work commitment among its labour force. Managerial support is consistently emphasized in discussions and studies as a factor influencing work life balance hence the need for them to come up with policies that enhance job satisfaction.

Men have traditionally been the primary breadwinners in most households; however, this role distinction has dramatically changed in industrialized countries Skitmore (2003). Research has found, not 
surprisingly, that women spend more time working in the household than men. Women are still largely responsible for maintaining the household, through tasks which include doing the laundry, shopping, food preparation and paying bills while spending 40 hours a week in the workplace O'Kelly (2003). This fact suggests that women should be experiencing more work life conflict than men. It is further purported that women with younger children would face more inner conflict than those with older children Noor (2003).

Virick (2006) suggest that men and women have different expectations for work and home. It was also argued that men have a higher need of affiliation than women and find that family experiences interfere with work. Understanding the roles of men and women in the workplace must include norms dictated by society. Women are expected to be more family focused than men, while men, who are considered the family providers, are more career conscious than women. Typically men spend more time at the office seeking career advancement while women are doing both, spending excessive time at the office while trying to maintain the family household. Men generally feel less pressured by societal expectations with respect to issues associated with family conflict; the male is expected to be the primary breadwinner. Women, conversely, allow society to create cultural pressures to stay home, raise children and take care of the household O'Conner (2005). Men accomplish one-third of daily home activities; women perform two-thirds. Therefore, if there are family conflicts and the woman is earning less than her husband, the woman is more than likely expected to leave the workplace.

Today, a man's success is generally associated with his work. Some want to become more involved at home, but it is much harder for men to utilize family-friendly policies over a long period O'Conner (2005). Working under these pressures has caused an increase in work-family conflict that has contributed to the growth of burnout, adverse attitudes, job dissatisfaction, decreased quality family time and workplace violence Noor (2002). Extended work hours and excessive workloads can influence work-family conflict and is the direct antecedent to work-family conflict Spector (2007).

How employees decide to invest time in given roles is determined by the amount of energy used in one domain over the other. Some individuals are more work focused than others, which can cause conflict in family roles Pocock (2008). Family-friendly policies were created to provide employees flexibility between work and family. This enables employees to meet commitments in both domains without having to choose one over the other. Organizations that provide flexible work schedules allow parents to care for their families while meeting work obligations during a given work cycle. For example, an employee may change work hours to meet with teachers or take their children or parents to the doctor Halpern (2005).

Flexible work hours are designed to keep employees motivated in a competitive business environment Boundary management enables individuals to coordinate role requirements and expectations to specific workfamily or family-work domains. How employees decide to invest time in given roles is determined by the amount of energy used in one domain over the other. Some individuals are more work focused than others, which can cause conflict in family roles Pocock (2008). Family-friendly policies were created to provide employees flexibility between work and family. This enables employees to meet commitments in both domains without having to choose one over the other. Organizations that provide flexible work schedules allow parents to care for their families while meeting work obligations during a given work cycle. For example, an employee may change work hours to meet with teachers or take their children or parents to the doctor Halpern (2005). Flexible work hours are designed to keep employees motivated in a competitive business environment .Prior research by Haar (2007) on the spill over effect have examined if work and home roles should be integrated or segmented. According to the type of provisions offered employees, there may be a combination of both work spill over and home spill over. Non-traditional working arrangements have been introduced by many corporations, such as job sharing, telecommuting and compressed work weeks to ensure employee flexibility.

Research suggests that job satisfaction is a direct result of work life Ryan (2002). There are programs that can provide less anxiety for working parents, such as job sharing, flexible work schedules and compressed work weeks; however, organizations must determine their measure of corporate engagement Marchese (2003). Work dissatisfaction is usually associated with specific attributes of a job, such as pay, promotion prospects, health care benefits or flexible hours at work. Research shows that satisfaction is closely associated with worker behaviour, such as absence from work, job change, and labour turnover. Brunton (2006), explain that effective work-life programs such as flexible work schedules, compressed work weeks, telecommuting, job sharing and onsite child care facilitates provide benefits to both the employer and the employee.

Employees that can better manage both work and family should be more satisfied, which in turn, can result in higher productivity, job satisfaction, commitment, job retention, and organizational loyalty. If employees are satisfied, job turnover and absenteeism should be reduced. There also might be increased job performance and financial gains resulting in reduced training and developmental costs Williams (2003). Research has gravitated to spill over models that explain how family and work-life is commingled. Mont (2006) addressed work/family conflict in terms of energy, attention and engagement rather than time, suggesting that time is transitioned to a mathematical proposition and energy to human concerns. Frone (2003) indicated there 
was a positive correlation between an employee's attitude and experiences in the work and family domains. The results of inter-role conflict can reduce job satisfaction and cause the family domain to become unsteady Kalliath (2005).

Flexible work hours are attributed to reducing bidirectional inter-role conflict; however, this may have more of an effect on family/work conflict rather than on work-family conflict Brough, (2005). Work-life conflict is the responsibility of both the employer and employee. Employers can identify ways to reduce workloads, overtime and job-related travel. Also, employers can reward overtime work, make alternative corporate work provisions available and implement career development and advancement programs. The employee is responsible for limiting the amount of job-related work at home, limiting the reliance on overtime hours, reducing business travel and becoming more knowledgeable about work-life policies Duxbury (2006).

Bass (2008) found that those with greater financial resources and status were less likely to have conflict between job satisfaction and work-family. Those employees with higher incomes can afford more assistance with non-work responsibilities, such as childcare and household chores Allen (2008) also reported that the greater the amount of family love and commitment, the more positive the relationship between job satisfaction and work-family conflict. Parkes et al (2005) research findings show that the relationship between job satisfaction and work-life balance is a greater factor in middle-aged employees with children than single employees under thirty. Working adults are engaged in their children's activities and make decisions between work and family. Single individuals under thirty might have more flexibility in their work schedules and family roles.

Nadeem (2009) tested a relationship of work life conflict and job satisfaction in a sample of Pakistani employees and revealed a negative relationship between the two variables and suggested that supportive management can be minimizing this conflict. Scandura and Lankau (1997) observe that flexible work hours lead to higher job satisfaction and organizational commitment for female employees and for employees with family responsibilities. According to Meeusen (2011) flexible work schedules lead to enhanced productivity, decreased absenteeism, improved commitment, and better recruiting. Grawitch and Barber (2010) performed a study to systematically review literature that concentrated its attention on work flexibility programs and nonwork support (family-friendly benefits). The outcome of the literature review demonstrated that there is a relationship between work-life programs and higher job satisfaction, performance, well-being, and commitment, as well as decreased turnover rates and distress. Mohr and Sochi (2006) show that several forms of job design raise satisfaction.

Burke (2002) observes that both women and men prefer working in organisations that support work-life balance. Men appeared to benefit more than women. Men feel more satisfied when they achieve more on the job even at the cost of ignoring the family. On the other hand, women stress that work and family are both equally important and both are the sources of their satisfaction. Marcinkus (2007) observes that work based support to women is positively associated with job satisfaction, organisational commitment and career accomplishment.

Mokaya and Gitari (2012) have tried to determine the effect of workplace recreation on employee performance at Kenya Utalii College and take attempt to cover aspects of job satisfaction, service quality, customer satisfaction, and employee productivity. According to a survey by Strathmore Business School in 2011, most Kenyan companies lack policies that support the well-being of the employees' families. The purpose of this survey was to assess the types of work-family policies present in Kenyan companies, and the degree in which their organizational culture promotes these policies.

Benin by Fourn (2009) showed that the perception of women on the issue of reconciliation of work and family varies depending on marital status .Employers are aware of this problem but lack incentive policies to improve women's performance on a professional level. The working environment of women shows that support measures offered are like the possibility of adjusting working days during pregnancy to the time of delivery, maternity leave, salary supplements in terms of family allowances and a guarantee of workstation after a period of absence.

Cotonou by Kombieni (2009) showed that professional women, manage their health better than those who do not work and that the more women climb the echelons in an enterprise the better they get at managing stress because of increased resources. In Kenya, work life balance policies have not been fully implemented and there hasn't been extensive research on work life balance policies and on job satisfaction. Therefore, there is a clear need for this research to fill that gap.

\section{Materials and Methods}

For the purpose of this study, the researcher adopted descriptive design using both open and closed ended questions to gather data to enable the analysis. This type of research attempted to describe such things as possible behaviour, attitudes, values and characteristics. This research design was found suitable since it offered the researcher a profile to describe relevant aspects of the phenomena from an individual, organisational and industry oriented perspectives. 


\section{Target Population}

The study targeted employees working in commercial banks which consisted of Two hundred and forty employees working in commercial banks in Nairobi Central business district.

\section{Sampling design and Sample Size}

The sampling frame describes the list of all population units from which the sample will be selected Cooper and Schindler (2007). From the population frame the required number of subjects, respondents, elements or firms will be selected in order to make a sample. A sample size of 60 respondents was arrived at as $25 \%$ of the target population of 240 .

Table 1: Sampling Frame

\begin{tabular}{lccc}
\hline Sections & Population, (Frequency) & Percentage & Sample size \\
\hline Top management & 15 & 6.25 & 3 \\
Middle level management & 45 & 18.75 & 11 \\
Lower level management & 180 & 75 & 45 \\
Total & 240 & 100 & 60 \\
\hline
\end{tabular}

\section{Data Collection Technique}

The researcher designed a questionnaire to gather extensive data and incorporated a five point likert rating scale. This enabled the researcher to assess employees' attitude towards work life balance policies and job satisfaction by asking the respondents how strongly they agree or disagree with series of statements. The questionnaire had both open and closed questions. The purpose of using questionnaires in the research is because of the direct response and feedback from the respondents that can be collected in short period of time and in an easier manner.

\section{Validity and Reliability}

To establish the content validity of the research instrument the researcher sought opinions of experts in the field of study especially the lecturers in the department of business administration. The reliability of the questionnaire was tested using Cronbach's Alpha which measures the internal consistency. Coefficient of 0.7 is a commonly used as the cut of point of acceptable reliability Nunnally (1978).

\section{Data Analysis and Presentation}

Before processing the responses, the completed questionnaires were edited for completeness and consistency. The questionnaires were then coded to enable the responses to be grouped into various categories. The researcher mainly used descriptive statistics and inferential statistics to analyze data. The information was displayed by use of bar charts, graphs and pie charts and in prose-form. Multiple regressions were used to determine the predictive power of the factors. Employee Job Satisfaction $(Y)$ was expressed as a function of Work Life Balance Policies specified in the following regression equation:

$$
\begin{aligned}
& Y=\beta_{0}+\beta_{1} X_{1}+\beta_{2} X_{2}+\beta_{3} X_{3}+\beta_{4} X_{4}+\varepsilon \\
& \text { Whereby } \quad Y=\text { Employee Job Satisfaction } \\
& \beta_{0}=\text { Constant } \\
& \beta_{1}-\beta_{4}=\text { Intercepts of Independent Variables } \\
& X_{1}=\text { Flexibility Policies } \\
& X_{2}=\text { Leave Provisions } \\
& X_{3}=\text { Welfare Policies } \\
& X_{4}=\text { Job Design } \\
& \varepsilon=\text { Standard Error term }
\end{aligned}
$$

\section{Results and Discussions}

The reliability of the questionnaire was evaluated through Cronbach's Alpha which measures the internal consistency. The Alpha measures internal consistency by establishing if certain item measures the same construct. Cronbach's Alpha was established for every objective in order to determine if each scale would produce consistent results should the research be done later on. The findings of the pilot study shows that all the 
four scales were reliable as their reliability values exceeded the prescribed threshold of 0.7 (Mugenda and Mugenda, 2003).

Table 2: Reliability Coefficients

\begin{tabular}{lcc}
\hline Scale & Cronbach's Alpha & Number of Items \\
\hline Flexibility Policies & 0.889 & 7 \\
Welfare Policies & 0.745 & 4 \\
Job Design & 0.693 & 6 \\
Leave Provisions & 0.833 & 6 \\
\hline
\end{tabular}

\section{Response Rate}

The study targeted 60 respondents in collecting data with regard to influence of work life balance policies on employee job satisfaction in the Kenyan banking sector. From the study, 54 out of the 60 sample respondents filled-in and returned the questionnaires making a response rate of $90 \%$. According to Babbie (2002) any response of 50\% and above is adequate for analysis thus $90 \%$ is even better. This reasonable response rate was made a reality after the researcher made personal calls and visits to remind the respondent to fill-in and return the questionnaires.

\section{Descriptive statistics}

The findings from the study were presented using descriptive statistics which included frequencies, percentages, means and standard deviations. The data was also presented using graphs and pie charts.

\section{Analysis of the Questionnaire}

Table 3: Flexibility Policies

\begin{tabular}{lr}
$\begin{array}{l}\text { Please Indicate the degree to which you agree to the following statements. Strongly Agree=1 Agree=2 Neutral=3 Disagree=4 Strongly } \\
\text { disagree=5 N=54 }\end{array}$ & Mean \\
\hline Flexibility Policies: & 2.0526 \\
& 2.1316 \\
I have experienced conflicts in schedule when it comes to family events and work. & .01127 \\
I believe that the banking industry is very labour intensive ( $24 / 7$ a week) and promotes & .01163 \\
conflicts between my work and my family. & .07061 \\
I believe that long daily and weekly working hours causes conflicts between my work and & .2211 \\
my relationships with my family. & .46299 \\
I don't have the possibility to personally decide over my starting and finishing time. & .3152 \\
My workplace doesn't provide technological resources that allow me to work from home if & 1.0474 \\
I have family affairs to attend to. & 2.1579 \\
I believe that the excessive demands of the clients interfere with my work and family. & .49834 \\
I have experienced mental distraction at work caused by non-fulfilment of family \\
obligations
\end{tabular}

The researcher sought to establish the level of agreement to various aspects of flexibility policies According to the findings the respondents agreed that they experience conflicts in schedule when it comes to family events and work as shown with mean of 2.0,the study further established that long daily working hours cause conflicts between work and family with mean of 2.2,that employees are not given a chance to decide their the time the start to work shown by a mean of 2.3 and that they are not provided technological resources to allow them to work at home shown by a mean of 1.04 .

Table 5: Welfare Policies

Please Indicate the degree to which you agree to the following statements. Strongly Agree=1 Agree=2 Neutral=3 Disagree=4 Strongly disagree $=5 \mathrm{~N}=54$

Welfare Policies:

I have experienced that my resources are highly affected by medical bills for my children

I have experienced that my work performance is affected by stress and anxiety over

Std. Deviation

childcare.

My supervisor doesn't understand when I talk about personal or family issues that affect my work.

The Organisation I work for doesn't extend resources to help me with my family

.16980 responsibilities

The researcher sought to establish the level of agreement to various aspects of Welfare Policies. According to the findings the respondents agreed that their resources are affected by medical bills for their children by a mean of 2.4 , their performance is affected by stress over childcare by a mean of 2.42 , their supervisors don't understand when they talk about this issues by a mean 2.38 and that the organisations they work for don't extend resources to help them with this responsibilities shown by a mean of 2.21 
Table 6: Job Design

Please Indicate the degree to which you agree to the following statements. Strongly Agree=1 Agree=2 Neutral=3 Disagree=4 Strongly disagree $=5 \mathrm{~N}=54$

\begin{tabular}{lc}
\hline Job Design: & Mean \\
$\begin{array}{l}\text { I am overworked and have neglected my family responsibilities due to inability to reject my co-workers } \\
\text { and managers. }\end{array}$ & 2.3368 \\
$\begin{array}{l}\text { My helpfulness behaviour or inability to say "no" to tasks given to me at work has caused family } \\
\text { disharmony. }\end{array}$ & 2.1737 \\
$\begin{array}{l}\text { My inability to reject my co-workers and managers' request to help at work has caused family } \\
\text { disharmony. }\end{array}$ & 2.1211 \\
$\begin{array}{l}\text { I believe that the high expectations of my supervisors cause conflicts between my work and my } \\
\text { relationships at home. }\end{array}$ & 2.0579 \\
$\begin{array}{l}\text { I believe that I would concentrate better on my job if I worked from a different workstation from time to } \\
\text { time }\end{array}$ & 1.6842 \\
I believe that if my work was less complex I would do it better & .21636 \\
\hline
\end{tabular}

The researcher sought to establish the level of agreement to various aspects of Job Design. According to the findings the respondents agreed that they are overworked and have neglected their family responsibilities shown by a mean of 2.33 , they are unable to reject requests by their co workers and managers to help out shown by 2.12 , that the high expectations of their supervisors cause conflicts with their families shown by a mean of 2.05 , they would concentrate better if they rotate workstations shown by a mean of 1.68 and the would like their work to be less complex shown by a mean of 1.85 .

Table 7: Leave Provisions

Please Indicate the degree to which you agree to the following statements. Strongly Agree=1 Agree=2 Neutral=3 Disagree $=4$ Strongly disagree $=5 \mathrm{~N}=54$

\begin{tabular}{lr}
\hline Leave Provisions: & Mean \\
& Std. Deviation \\
I get compensated not to take leave & 2.3947 \\
I have carried forward leave days from previous year & 2.0526 \\
I don't get time off to study and develop myself professionally & .10024 \\
I cannot schedule my preferred day-offs supported by my co-workers or supervisor. & .22355 \\
I don't get time off from my duties when I am not feeling well & .0263 \\
I don't get time off to take care of family emergencies & 1.8947 \\
\end{tabular}

The researcher sought to establish the level of agreement to various aspects of Leave Provisions. According to the findings the respondents agreed that they get compensated not to take leave by a mean of 2.39 , they have carried leave days forward by a mean of 2.05, they don't get time off to study by a mean of 2.02, they are not able to schedule preferred leave days by a mean of 1.89 they don't get leave when they are sick by a mean of 2.44 and that they don't get time off to take care of family emergencies by a mean of 2.10 .

Table 8: Employee Job Satisfaction

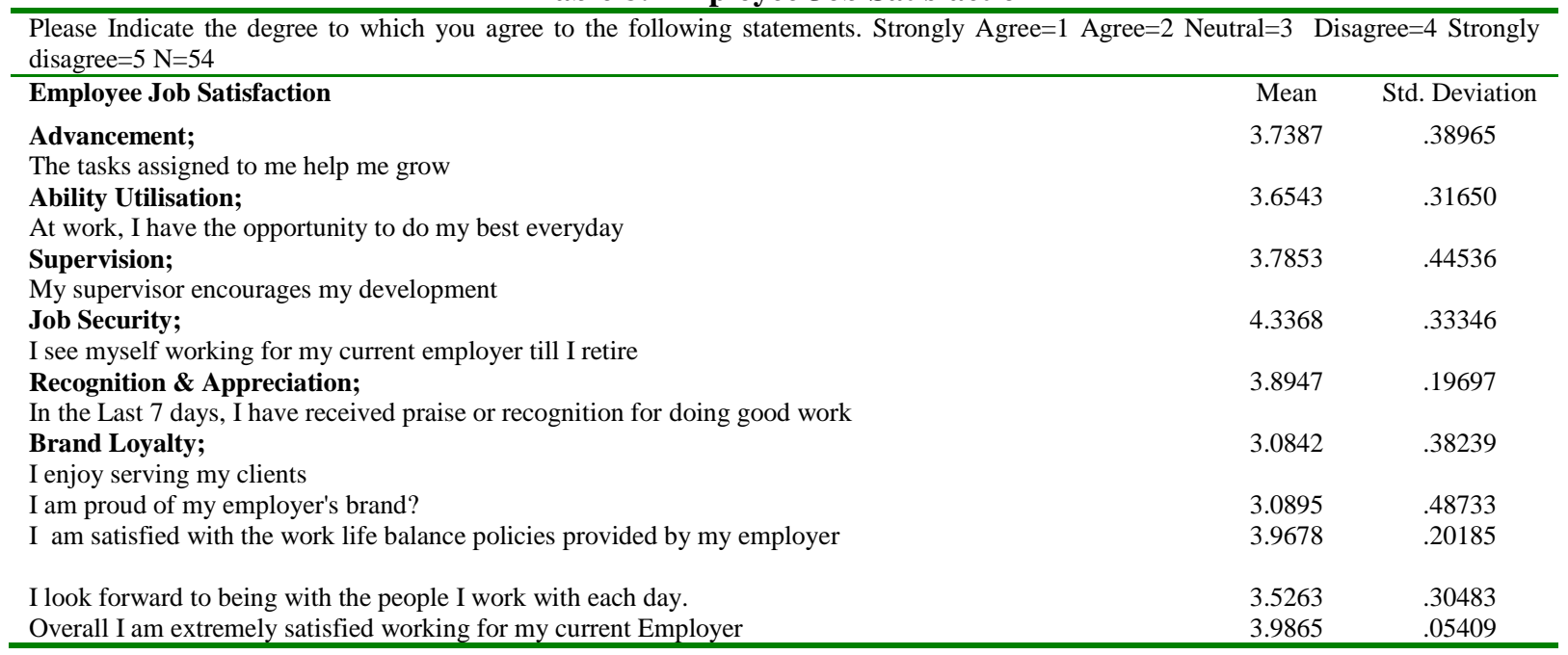

The researcher sought to establish the level of agreement to various aspects of Job Satisfaction. According to the findings the respondents disagreed to most of these aspects, the respondents disagreed that the tasks assigned to them help them grow by a mean of 3.7, that there have the opportunity to do their best at work by a mean of 3.65 , that their supervisors encourage their development by a mean of 3.78 , that they intend to work for their employer till they retire by 4.33 , that they have received recognition for a job well done by a 
mean of 3.89. they were neutral about enjoy serving their clients by a mean of 3.08 and being proud of their employers brand 3.08. When asked how satisfied they were of the work life balance policies provided by their employers they were unsatisfied by a mean of 3.9678, they didn't look forward to working with their workmates by a mean of 3.5 and they were in the overall unsatisfied working for their current employer by a mean of 3.98.

\section{Correlation and regression analysis}

Correlation analysis was used to establish the relationship between the study variables while multiple regression analysis was used to estimate the predictive of influence of work life balance policies on employee job satisfaction in the Kenyan banking sector. Inferential statistics namely Pearson's product moment correlation analysis was employed for the study variables. Pearson's product moment correlation tests were chosen in order to assess whether there is a relationship between the study variables. The method was also chosen because a rating scale was used in the questionnaire. As shown in table, independent variables had the following Pearsons moment correlation coefficient on leave provisions $(r=0.194)$, welfare policies $(r=0.659)$, flexibility policies $(r=0.561)$, Job design $(r=.132)$. In order to establish the strength of the relationship between flexibility policies and employee job satisfaction, the results showed there existed a strong and positive correlation between flexibility policies and employee job satisfaction $(r=0.561)$. Leave provisions $(r=$ 0.194), shows there exists a low correlation between leave provisions and employee job satisfaction, the results showed there existed a positive correlation.

Job Design and employee job satisfaction, the results showed there existed a weak and positive correlation between welfare policies and employee job satisfaction $(r=0.132)$. Welfare policies and employee job satisfaction, the results showed there existed a strong and positive correlation between welfare policies and employee job satisfaction $(r=0.659)$.

Table 9: Correlation of the Study Variables

\begin{tabular}{|c|c|c|c|c|c|c|}
\hline & & $\begin{array}{c}\text { Flexibility } \\
\text { Policies }\end{array}$ & $\begin{array}{c}\text { Leave } \\
\text { Provisions }\end{array}$ & $\begin{array}{l}\text { Welfare } \\
\text { Policies }\end{array}$ & Job Design & Job Satisfaction \\
\hline Flexibility & Pearson & 1 & & & & \\
\hline \multirow[t]{2}{*}{ Policies } & $\begin{array}{l}\text { Correlation } \\
\text { Sig. (2-tailed) }\end{array}$ & & & & & \\
\hline & $\mathrm{N}$ & 54 & & & & \\
\hline Leave & Pearson & $.376(* *)$ & 1 & & & \\
\hline \multirow[t]{3}{*}{ Provisions } & Correlation & & & & & \\
\hline & Sig. (2-tailed) & .003 & & & & \\
\hline & $\mathrm{N}$ & 54 & 54 & & & \\
\hline Welfare & Pearson & $.436(* *)$ & $.714(* *)$ & 1 & & . \\
\hline \multirow[t]{3}{*}{ Policies } & Correlation & & & & & \\
\hline & Sig. (2-tailed) & .000 & .000 & & & \\
\hline & $\mathrm{N}$ & 54 & 54 & 54 & & \\
\hline \multirow[t]{3}{*}{ Job Design } & $\begin{array}{l}\text { Pearson } \\
\text { Correlation }\end{array}$ & .001 & $.328(*)$ & $.361(* *)$ & 1 & \\
\hline & Sig. (2-tailed) & .993 & .010 & .005 & & \\
\hline & $\mathrm{N}$ & 54 & 54 & 54 & 54 & \\
\hline \multirow[t]{3}{*}{ Job Satisfaction } & $\begin{array}{l}\text { Pearson } \\
\text { Correlation }\end{array}$ & .561 & $.194(* *)$ & $.659(* *)$ & .132 & 1 \\
\hline & Sig. (2-tailed) & .138 & .000 & .000 & .314 & \\
\hline & $\mathrm{N}$ & 54 & 54 & 54 & 54 & 54 \\
\hline
\end{tabular}

** Correlation is significant at the 0.01 level (2-tailed).

* Correlation is significant at the 0.05 level (2-tailed).

\section{Regression analysis}

A multivariate regression model was applied to determine the relative importance of each of work life balance policies on employee job satisfaction in the Kenyan banking sector. The regression model was as follows: $Y=\beta_{0}+\beta_{1} X_{1}+\beta_{2} X_{2}+\beta_{3} X_{3}+\beta_{4} X_{4}+\varepsilon$, Using the values of the coefficients $(\beta)$ from the regression coefficient Table 10 the established multiple linear regression equation takes the form of; $Y=5.056+0.207 X_{1}+0.178 X_{2}+0.422 X_{3}+0.161 X_{4}$

Where; Constant $=5.056$; when value of the independent variables are zero, the job satisfaction would take the value 5.056. $X_{1}=0.207$; One unit increase in flexibility Policies results in 0.207 units increase in the Job satisfaction. $X_{2}=0.178$; One unit increase in leave provisions results in 0.161 units increase in the Job 
satisfaction. $X_{3}=0.422$; One unit increase in welfare policies results in 0.422 units increase in the Job satisfaction. $X_{4}=0.161$; One unit increase in job design results in 0.161 units increase in the Job satisfaction. Ranking the predictors variables in terms of their individual influence on the job satisfaction, the table shows the relative importance of each the predictions i.e. welfare policies had the highest influence (0.422), flexibility policies $(0.207)$, and leave provisions (0.178) and finally Job design (0.161) respectively.

Table 10. Regression Coefficient

\begin{tabular}{llccccc}
\hline Model & & \multicolumn{2}{c}{$\begin{array}{c}\text { Unstandardized } \\
\text { Coefficients }\end{array}$} & $\begin{array}{c}\text { Standardized } \\
\text { Coefficients }\end{array}$ & T & Sig. \\
\hline \multirow{3}{*}{1} & & B & Std. Error & Beta & B & Std. Error \\
& (Constant) & 5.056 & 3.061 & & 1.652 & .104 \\
& Flexibility Policies & .207 & .039 & .472 & 5.328 & .030 \\
& Leave Provisions & .178 & .058 & .375 & 3.063 & .003 \\
& Welfare Policies & .422 & .079 & .623 & 5.344 & .000 \\
& Job Design & .161 & .073 & .204 & 2.221 & .030 \\
\hline
\end{tabular}

Dependent Variable: Job satisfaction

Table 11. Model Summary

\begin{tabular}{ccccc}
\hline Model & R & R Square & Adjusted R Square & Std. Error of the Estimate \\
\hline 1 & .803 & .644 & .618 & .78381 \\
\hline
\end{tabular}

The results as shown in the Table 11 indicate that the four independent variables explained a $61.8 \%$ of the variation in the dependent variable. Therefore, the remaining $38.2 \%$ is explained by other factors not considered in this study.

\section{Conclusion}

The objective of the study was to determine the Influence of work life balance policies on job satisfaction in the Kenyan Commercial Banks and specifically to assess the flexibility policies, welfare policies, job design options and their leave provisions. The results showed that there was positive relationship between the independent and the dependent variables. This was shown by their correlations on Table 9. The regression results also concurred with the correlation results as also indicated on Table 10. It can therefore be concluded that the management of the commercial banks in central business districts need to consider all the variables considered in this study in order to improve the job satisfaction of their employees and consequently this will improve the performance of the financial institutions.

\section{References}

[1] Mugenda, O. and Mugenda, A. (2003), Research Methods: Quantitative and Qualitative Approaches, Acts Press, Nairobi. Vol.5. pg 21

[2] Mokaya, S. and Gitari, J. (2012), Effects of Workplace Recreation on Employee Performance: The Case of Kenya Utalii College, International Journal of Humanities and Social Science, 2(3):176-183.

[3] Malik, M..(2011).Role Overload,job satisfaction and their effect on layoff survivor's Job Retention and Productivity.Interdisciplinary Journal of contemporary Research in Business,2(11):427-440.

[4] Varatharaj, V. and Vasantha, S. (2012), Work Life Balances a Source of Job Satisfaction - an Exploratory Study on the View of Women Employees in the Service Sector, International Journal of Multidisciplinary Research, 2(3): 450-458.

[5] Danish,R..,\& Usman, A.(2010).Impact of Reward and Recognition on Job Satisfaction and Motivation: An Empirical Study from Pakistan.International Journal of Business and Management, 5 (2):159-167.

[6] Eikhof,D.., Warhurst, C., \& Haunschild, A. (2007). Introduction what work? Whatlife?What balance?Journal of Employee Relations, 29 (4): $325-333$.

[7] Auko, Y. (2009), Work-Family Conflict and Coping Strategies Adopted by Women in Academia. Gender and Behaviour, 7 (1), 2095-2122

[8] Lee, C. , Elke D.and Dobson, R. (2009), Work-Life Balance for Early Career Canadian Psychologists in Professional Programs Canadian Psychology:Canadian Psychological Association, 50 (2), 73-82

[9] Torrington, D., Hall, L., and Taylor, S. (2009), Human Resource Management 7th Ed. London: Prentice Hall. London: Prentice Hall

[10] Lewis, S., Rapoport, R. and Gambles, R. (2007), The Constraints of a Work Life Balance Approach: An International Perspective. The International Journal of Human Resource, 18(3), 360-373

[11] Harrison, D., Newman, D., \& Roth, P. (2006), How important are job attitudes? Meta-analytic comparisons of integrative behavioural outcomes and time sequences: Academy of Management Journal, 49, 305-325

[12] Alfredsson, Karin. (2005), "Equal Opportunities: Sweden Paves the Way", Stockholm: Swedish Institute

[13] Barnett, R., and Rivers, C. (2004), Same Difference: How Gender Myths are Hurting Our Relationships, Our Children, and Our jobs. New York: Basic Books

[14] Jackson, S.E., \& Schuler, R.S. (2003), Managing human resources through strategic partnerships.(8th ed.) Mason, Ohio: ThomsonSouthwestern

[15] Armstrong, M. (2002), A handbook of human resource management practice: London, Kogan page 
[16] Allen, T., Herst, D., Bruck, C., \& Sutton, M. (2000). Consequences associated with work-to-family conflict: A review and agenda for future research. Journal of Occupational Health Psychology, 5(2), 278-308.

[17] Bhuian, S., Menguc, B., \& Borsboom, R. (2005). Stressors and job outcomes in sales: A triphasic model versus a linear-quadraticinteractive model. Journal of Business Research, 58, 141-150.

[18] Boyar, S., \& Pearson, A. W. (2005). The effects of work-family conflict and family-work conflict on nonattendance behaviors:Journal of Business Research, 58(7), 919-925.

[19] Butler, A., \& Skattebo, A. (2004). What is acceptable for women may not be for men: The effect of family conflicts with work on job performance.Journal of Occupational and Organizational Psychology, 77, 553-564.

[20] Carmeli, A. (2003). The relationship between emotional intelligence and work attitudes, behavior and outcomes. An examination among senior managers: Journal of Managerial Psychology, 18(8), 788-813.

[21] Demerouti, E., Bakker, A. B., \& Bulters, A. J. (2004). The loss spiral of work pressure, work-home interference and exhaustion: Reciprocal relations in a three-wave study. Journal of Vocational Behavior, 64(1), 131-149.

[22] Elit, L., Trim, K., Mand-Bains, I. H., Sussman, J., \& Grunfeld, E. (2004). Job satisfaction, stress, and burnout among Canadian gynecologic oncologists:Gynecologic Oncology, 94, 134-139.

[23] Karatepe O., \& Sokmen A. (2006). The effects of work role and family role variables on psychological and behavioral outcomes of frontline employees: Tourısm Management , 27(2), 255-268.

[24] Karatepe, O, \& Tekinkus, M. (2006). The effects of work-family conflict, emotional exhaustion, and intrinsic motivation on job outcomes of frontline employees:International Journal of Banking Marketing, 24(3), 173-193.

[25] Kinunen, U., Vermulst, A., Gerris, J., \& Makikangas, A. (2003). Work-family conflict and its relations to well-being: The role of personality as a moderating factor. Personality and Individual Differences, 35, 1669-1683. 